Owing to exposure difficulties very old temperature readings can seldom be relied on for such minute changes. Nevertheless glaciers with a scale of perhaps several kilometres per degree provide a wonderful instrument for this purpose. Their value in this respect should be even greater when we have more basic knowledge of their response both to precipitation and temperature. When this method is used accuracy will be much increased if it is possible to secure dimensional changes from several glaciers in any region, but care must be taken to avoid ice streams with exceptional morphological characteristics or large changes of gradient such as deep ice falls.

MS. received ro February $195^{\circ}$.

\title{
THE ORIGIN OF DIRT CONES ON GLACIERS
}

\author{
By Charles Swithinbank \\ (Oxford University Exploration Club)
}

Paper communicated to a Meeting of the Society on 17 February 1949

\begin{abstract}
The characteristics and probable development of dirt cones on Vatnajökull (Iceland) are described. Thick accumulations of debris protect the ice beneath them from ablation, whereas thin ones accelerate the process. Under given conditions of ablation, the nature of the debris covering is the deciding factor-in particular its radiation under given confitions of ablation, the nature of the Contrasts are noted between the dirt cones of Vatnajökull and those of other glaciers. The nature of the debris and of the ablation varies greatly from place to place, but all dirt cones result from differential ablation.

ZuSAMMENFASSUNG. Die Kennzeichen und wahrscheinliche Entwicklung von Eisschmelzkegeln auf Vatnajökull (Island) sind beschrieben. Dichte Schuttanhäufungen schützen das Eis darunter vor Ablation, wogegen leichte Anhäufungen dieser Art den Prozess beschleunigen. Unter gegebenen Ablationsverhältnissen ist die Beschaffenheit der Schuttdecke ausschlaggebend, vor allem deren Strahlungs-Absorptionskoeffizient, Leitungsfähigkeit und der Schuttdecke ausschlaggebend, vor allem deren Sträkull und andern Gletschern sind angegeben. Die Dicke. Gegensätze zwischen Eisschmelzkegeln auf Vatnajokull und andern Gletschern sind angegeben. ihren Ursprung in Differential-Ablation.
\end{abstract}

\section{INTRODUCTION}

Dirt cones are found on snow and on ice in both arctic and temperate regions. In Iceland it is not unusual to see many hundreds of them from $\mathrm{I}$ to $3 \mathrm{~m}$. high, scattered like so many ash heaps over the marginal areas of the glaciers. In exceptional circumstances they may be $30 \mathrm{~m}$. high. Similar forms have been described on the Malaspina Glacier. There they frequently reach a height of $24 \mathrm{~m} .{ }^{1}$ On the Hispar Glacier a cone was estimated to rise to $85 \mathrm{~m}$. above the level of the surrounding ice surface. ${ }^{2}$

The name "dirt cone" is an unfortunate one, but convenient. It will be used here, since others are unwieldy. The mounds are seldom perfectly conical, being found in a great variety of irregular shapes. The term is also misleading in that it implies that the cones are formed entirely of debris. They are in fact cones formed of pure snow or ice, covered with but a thin veneer of material. Ice pyramids are distinguished from dirt cones by the absence of any such covering.

\section{A. Dirt Cones on Vatnajökull}

\section{CONES WITH ICE CORES}

While taking part in the Oxford University expedition to Iceland in 1947 I was able to examine a number of dirt cones. Within a kilometre or so of the margin of Skaftárjökull, one of the southwestern outlet glaciers of Vatnajökull, at an altitude of about $800 \mathrm{~m}$. above sea level, very many black mounds rise, on an average about $2 \mathrm{~m}$. above the level of the surrounding ice (see Fig. I, p. 439). The majority occur along crevasse lines. Apart from this, however, there is no regular arrangement. The crevasses, which vary in size from mere cracks in the ice to open fissures $\mathrm{I} \mathrm{m}$. 
wide and about $12 \mathrm{~m}$. deep, are arranged in two main groups running at right angles to each other. The cones are most frequent near the ice margin and near nunataks, that is, where there are most crevasses. With an increase in altitude and in distance from the ice margin their size decreases steadily until at about $1050 \mathrm{~m}$. they practically disappear. Isolated cones are however found even above the firn line (1 $100 \mathrm{~m}$.). At first sight the relation which exists between crevasses and the black dust makes each mound appear to have been squeezed up like toothpaste on the closing of a crevasse. The presence of the ice core, however, shows that the whole cone could not have resulted from this process.

A typical example is shown in Mr. W. V. Lewis's photograph shown in Fig. 2, p. 439. The top of the ice core was covered with a stratified deposit of fine black dust, the particles of which were held together by moisture. The sides of the cone were only thinly covered, and the ice core was showing through in places.

At the apex of the ice core of other mounds on Vatnajökull there was a V-shaped groove which was filled with dust. Normally this groove was completely hidden beneath the deposit.

\section{Origin of superficial material}

It seems reasonably certain that this consists of windblown dust of volcanic origin. In March of 1947 Hekla erupted, scattering ash over a large part of Iceland. No doubt a great deal fell on Vatnajökull. In normal times, however, much of the debris on the glacier must be derived from the bare deserts of basalts and ancient lava flows which lie to the north and north-west.

\section{Accumulation of superficial material}

In the ablation area, where almost all dirt cones occur, dust is moved by the action of melt water and rain into every little crevice on the surface of the ice. Larger masses are concentrated in hollows, and melt-water streams carry quantities of the dust into crevasses, where it forms sometimes stratified and sometimes irregular deposits.

\section{Development}

The first account of the probable origin of dirt cones was given by Agassiz ${ }^{3}$ in 1840 . Lewis 4 has gone into the subject in great detail, and has offered an explanation of the cones which he found on the northern margins of Vatnajökull. There is no reason to believe that these develop in a very different way to those on Skaftárjökull, and I shall use several of his ideas in suggesting the probable evolution.

The dust at the top of each cone is the remains of a deposit in the bottom of a crevasse or hollow (Fig. 3 (a), p. 463). At first, the level of the surrounding glacier surface is lowered until the dust reaches the surface so that the deposit can spread (Fig. $3(b)$ ). As ablation proceeds, the dust which has thus spread protects the ice beneath it and comes to rest on a pedestal of ice a few centimetres above the level of the surrounding glacier surface (Fig. $3(c)$ ). Dust begins to fall from the sides of the deposit, exposing the edges of the pedestal, which then undergoes ablation. Thus the sides of the pedestal, encroaching upon the centre, form the core of the incipient dirt cone (Fig. $3(d)$ ). The bottom of the slope is protected by fallen dust, and the sides gradually become less steep until they can hold material which has slipped from above. The angle does not continue to decrease, however, since the difference in level becomes greater as a result of the level of the surrounding ice continuing to fall. Eventually a slope is reached which represents the "angle of rest" * of the superficial material (Fig. $3(e)$ ). The majority of dirt cones on Vatnajökull have sides sloping at about 40 degrees.

\footnotetext{
*. The term angle of rest is used here for lack of a better. It does not mean that the dust on the sides of the cone is stable; only that it probably never falls bodily away leaving the whole side bare. The slope is constant only for a given quantity of water present in the deposit.
} 
The cleft in the top may represent the remains of a crevasse which existed at a time when the glacier surface was several metres above its present level. With the progressive lowering of the surface, all that remains is the narrowing crack which once existed at the crevasse bottom.

\section{Cyclic character of the development}

The formation of dirt cones on Vatnajökull suggests some kind of cycle. The development of a cone similar to that in Fig. 2 could take place as follows : the dust would gradually be removed by rain, being washed down the sides and eventually carried away by surface run-off or by melt water streams, leaving only a small accumulation on the summit. Instead of a cross section of the cone appearing to have concave sides, they would slope evenly. Soon the dust on top would become insufficient to protect the ice beneath. With a thin coating of dust, melting would proceed more rapidly than on the surrounding glacier ice. The cone would therefore eventually disappear completely.

On Skaftárjökull there were dirt cones in all stages of decline. There were also many patches of dust, about $0.5 \mathrm{~cm}$. deep, lying on almost level planes of hard glacier ice. These sometimes covered irregularly shaped but continuous areas up to 2000 square metres or more. It was apparent that some represented a late stage in the destruction of one or more dirt cones.
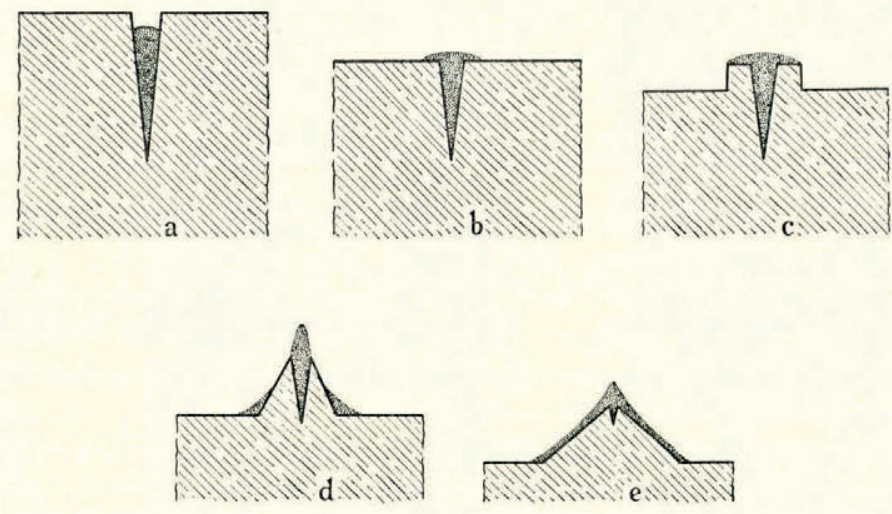

Fig. 3

\section{Transference of heat involved}

The black dust which is so frequently in evidence on the surface of Vatnajökull absorbs a large proportion of the available radiation, whereas the surrounding ice reflects it. Against this must be set the protection the dust provides from ablation due to rain and warm winds. By far the greater part of the ablation in summer on this glacier is of this type, and is not due to direct radiation. Much of the heat from both sources, which the material absorbs, is dissipated by conduction and radiation into the surrounding air. Some, however, remains. The conductivity of the material itself is low, and the amount of heat which it transmits to the ice beneath varies according to the thickness, nature and structure of the deposit.*

\section{Rate of development}

A seasonal cycle of development seems likely, though there are no records of observations on particular dirt cones during the consecutive years. The annual total of ablation on the southern

* In a recent paper on the same subject (American fournal of Science, Vol. 247, May 1949, p. 289-315) Sharp has elaborated this point by stressing the importance of grain size, water content and colour. 
margins of Vatnajökull is in the region of $3.2 \mathrm{~m}$. of water, ${ }^{5}$ and so it is probable that cones of about this height are formed within a single season. Some of the largest have been preserved beneath the winter snows, and are the product of several years' ablation. If the majority of cones start their cycle of development at the commencement of an ablation season, then late summer should be characterized by a preponderance of older ones.

\section{CONES CAUSED BY OVERTHRUSTING}

Another type of dirt cone, of different origin to those already described, is found interspersed among the others on Vatnajökull. In places where the surface is covered with considerable quantities of debris there are numerous parallel lines of brown-coloured cones. The individual examples are sometimes so close together in a line that they form almost continuous ridges. The distinctive features are almost always the colour and coarser nature of the debris, which consists of anything from boulders to fine mud, and sometimes contains large fragments of clear ice. This type is only found within $200 \mathrm{~m}$. or so of the ice margin, where the surface itself is becoming steeper. Frequently the ice on the upstream side is thrust over that on the downstream side. Some of the overthrusts meet the surface along a line of these brownish cones. Lewis ${ }^{4}$ has explained the origin of similar features on the northern margins of Vatnajökull. Overthrusting carries the debris to the surface from beneath the glacier, and the cones develop as a result of protection from ablation, in the same manner as those formed from windblown material. I. R. Menzies, in an unpublished communication, has ascribed a similar origin to cones which he saw on the southwest side of Drangajökull during the Cambridge Iceland Expedition, 1947.

\section{CONES WITH SNOW CORES}

Dirt cones are quite common on snow, and particularly on old snowfields. Fig. 4 (p. 439) shows a snow patch resting on terminal moraine at Kverkfjöll. The surface is covered with closely packed dirt cones, from a few centimetres to about $\mathrm{I} \mathrm{m}$. in height. The development of these cones is probably very similar to the development of those with ice cores. The manner of collecting debris, however, is different. In this case the proximity of moraine and of the outwash plain has caused large quantities of material to be blown on to the snow patch. In fact, the accumulation must become quite thick enough to protect the ice beneath it without being concentrated by melt-water streams. The inception of dirt cones in such circumstances is traceable to the original unevenness of the snow-field causing variations in the thickness of the superficial deposit. The effect of ablation is to accentuate the depth of any initial concavity, however slight.

A seasonal cycle of development seems probable with dirt cones on snow, as ablation rapidly lowers the surface in summer, and cones reach their full height within a few months.

\section{B. Dirt Cones on Jan Mayen}

Flint ${ }^{6}$ describes similar features on Sørbreen, the South Glacier, which he claims result from debris being squeezed up along "transverse fissures from subglacial positions." It is hard to conceive of any forces which would squeeze up material from beneath the ice. He also saw narrow "transverse fissures" through which fine, pasty black material was oozing out. Here some sort of squeezing up does seem possible since the debris has not to be brought the whole way from the bed of the glacier. The material was fine in grain, and could easily have been blown on to the ice. Then it may have been concentrated in a crevasse by melt-water streams, and squeezed up to the surface when the crevasse closed. The material was not held in any matrix of ice which would tend to resist the process. In this connexion it has been noted that dirt cones on Vatnajökull at first sight appear to have been squeezed up like toothpaste from crevasses. There too the material was pasty, and it seems quite possible that some may occasionally be squeezed from a closing crevasse. It is most unlikely, though, that all the dust which goes to form a dirt cone ever reaches 
the surface in this way. The possibility of such squeezing does not, of course, affect the cycle of development of the cones on Vatnajökull.

\section{Dirt Cones in Alaska}

Russell describes some dirt cones, of wholly different origin, which occur in front of receding glaciers. Large, debris-covered masses of ice, "several tens of feet" high, become separated from the main mass and on melting assume conical shapes. He has seen cones like this in front of the Spencer and Meldenhall Glaciers.

\section{Moraine Ridges in Antarctica}

No dirt cones similar to any which have been described above have been found in the Antarctic. Ablation forms with much in common have, however, been seen. Wright ${ }^{7}$ noted that medial moraines, when of sufficient density to protect the ice beneath, developed into rock-covered ice standing from $20 \mathrm{ft}$. $(6 \mathrm{~m}$.) to $50 \mathrm{ft}$. ( $15 \mathrm{~m}$.) above the general level of the glacier.

\section{E. Dirt Cones in the Himalaya}

Dirt cones have been seen on very many Himalayan glaciers. The majority of dirt cones are below the firn line, between $3400 \mathrm{~m}$. (I I,000 ft.) and $4000 \mathrm{~m}$. (I5,000 ft.), 8 and the superficial material varies from coarse moraine to sand and mud. Workman ${ }^{9}$ notes that on the lower threequarters of the Biafo Glacier, and on the Hispar Glacier and its branches, they vary in height from ro $\mathrm{cm}$. to $3 \mathrm{~m}$. They seem to have no regular arrangement, and some stand alone, some are in groups or lines, on level surfaces, in hollows, on the tops of seracs and on hillocks. In places the glacier ice is stratified in perpendicular, longitudinal strata which pass up through the pinnacles, thus showing them to be formed from glacier ice. ${ }^{10}$ An interesting point is that the cores of all the pinnacles are formed of very hard, compact, crystalline ice, unlike the soft, aerated ice which surrounds them.* 9 Though the method of collecting debris may not be the same, the Himalayan dirt cones are generally believed to be formed as a result of differential ablation, in the same manner as those in other parts of the world. No doubt a large proportion of the ablation at these altitudes is due to the incoming radiation, which, with the high angle of incidence of the sun, is very great. The orientation of the sun, however, does not affect the orientation of the cones, 8 showing that the original trend of the debris accumulation is the strongest factor influencing the direction in which they face. Himalayan dirt cones have been classified as "debris-conditioned nieve penitente." 9 This term seems a bad one, since it might confuse dirt cones with debris-or "pocket-penitente," a very different phenomenon.

\section{R E F E R E N C E S}

I. Russell, I. C. The Malaspina Glacier. Fournal of Geology, Vol. 1, No. 3, 1893, p. 231.

2. Workman, F, B. and W. H. The call of the snowy Hispar. London: Constable \& Co., I910, p. 263.

3. Agassiz, L. Etudes sur les glaciers. Neuchâtel : H. Nicolet, 1840, p. 132. 4. Lewis, W. V. Dirt cones on the northern margins of Vatnajökull. Fournal of Geomorphology, Vol 3, No. 1, 1940,
p. 16-26.

5. Ahlmann, Hans W:son. Glaciological research on the north Atlantic coasts. R.G.S. Research Series: No. I. London : Royal Geographical Society, 1948, p. 53.

6. Boyd, Louise A. The coast of northeast Greenland. New York: American Geographical Society, Special Publication No. 30,1948 , p. ror.

7. Wright, C. S. and Priestley, R. E. British (Terra Nova) Antarctic Expedition 1910-1913. Glaciology. London: Harrison and Sons, 1922, p. 287.

8. Workman, F. B. and W. H. Peaks and glaciers of Nun Kun. London: Constable \& Co., Ltd., 1909, p. 192-94.

9. Workman, W. H. A study of Nieve Penitente in the Himalaya. Zeitschrift für Gletscherkunde, Bd. 3, Heft 4, r 909 , p. $260-63$.

ro. Workman, F. B. and W. H. The call of the snowy Hispar. London: Constable \& Co., 19ro, p. 194.

II. Workman, W. H. Nieve Penitente and allied formations in the Himalaya. Zeitschrift für Gletscherkunde, Bd. 8, Heft 5, 1914, p. 308.

* These should not be confused with ice pyramids. $-E d$. 